\title{
"A compliment to Canadian medicine": Sir Thomas Roddick addresses the British Medical Association in Montréal
}

$\mathrm{T}$ wo events in 2012, the centennials of both the birth of the Medical Council of Canada and the death of Joseph Lister - the originator of antiseptic/aseptic surgery, ${ }^{1}$ can be serendipitously connected through the surgeon, Thomas Roddick, especially by his presidential speech delivered in 1897 to the British Medical Association (BMA) in Montréal, Que. One can include a third commemoration, the Diamond Jubilee of the reigning British monarch, which had been celebrated only once before, in 1897 - in which Roddick also played a role.

Born in Harbour Grace, Newfoundland, a son of the town's Scottish schoolmaster, Thomas Roddick (1846-1923), graduated MD CM from McGill University in $1868 . .^{1}$ In the 1870 s, he visited Scotland, England and Europe on a selffunded program of continuing medical education during which he acquired the latest surgical ideas, equipment and techniques. Exemplary was his experience of Listerism - the surgical wound management system devised by Joseph Lister to inhibit the growth of germs by carbolic acid, sprayers, impregnated gauze and other "antiseptic" dressings, and ligatures. At Edinburgh and London where Lister taught and practised, Roddick learned "antiseptic surgery" from the master. Roddick was not the only Canadian to learn directly from Lister, but given his teaching position at McGill and his surgical experience at the Montréal General Hospital he was well placed to influence colleagues and students and "convert" them to the tenets of the new antiseptic technique. ${ }^{2}$

In addition to being a successful surgeon, Roddick was cultured and ambitious; he was elected to Parliament (1896-1904); served as McGill's medical dean (1901-08); and was knighted

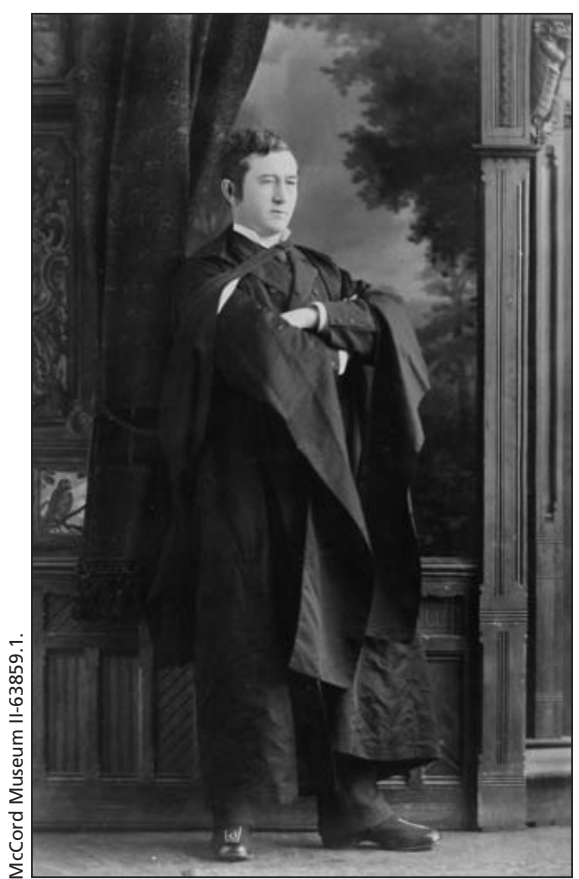

Dr. Roddick, Montréal, Que., 1882.

in 1914. Nestled among these achievements were Roddick's presidency of the BMA and his hosting of the annual conference of this group in Montréal in 1897, the first time that the BMA had met outside of Britain. The success of this event was pivotal to Roddick's career as he became the public face of this august gathering of American, British and Canadian doctors. The British Medical Journal (BMJ) leading up to the September meeting encouraged BMA members to make the transAtlantic trip, noting the many events and attractions that Canada and the conference had to offer. About 1100 people attended, most of whom were British.

This was a landmark event for Canadian medicine. The year marked the Diamond Jubilee of Queen Victoria, but unlike the analogous celebrations of 2012, those marking the 1897 event were cloaked in the trappings of the
British Empire. The achievements of Victorian medicine, science, and technology in the United Kingdom were celebrated and couched in the culture of colonialism and nationalism with "pomp and spectacle, and were an imperial rather than a British event." Amidst this admixture of pride of accomplishment and mawkish sentiment straddled Joseph Lister, lionized at the time as the embodiment of science, medicine, technology and empire. Lister had been President of the BMA, was President of the Royal Society of London (the oldest scientific society in existence), and also President of the British Association for the Advancement of Science (then meeting in Toronto in 1897); similarly, in 1897, he was raised to the peerage to become Lord Lister the first medical man ever to achieve this high rank. And, the illustrious Lister would be in attendance at the Montréal meeting as the honoured guest of the BMA and its Canadian hosts, especially president-elect Roddick.

Roddick's Montréal BMA presidential address reveals his awareness of the intellectual, social, cultural and political strands already identified; his speech remains a historical snapshot of the high-Victorian era in Canada. ${ }^{4}$ The BMA's decision to meet outside of Britain, Roddick made clear, was "not a personal matter, but a compliment to Canadian medicine" and one "which will serve still more to impress upon the memory of our people the year 1897, the year of the Diamond Jubilee of our beloved Sovereign Queen Victoria. In no part of her vast empire - not even its very heart did her subjects celebrate the great event with more enthusiastic loyalty and devotion than in Canada, especially in this province, the home of the French Canadians. We Canadians of 


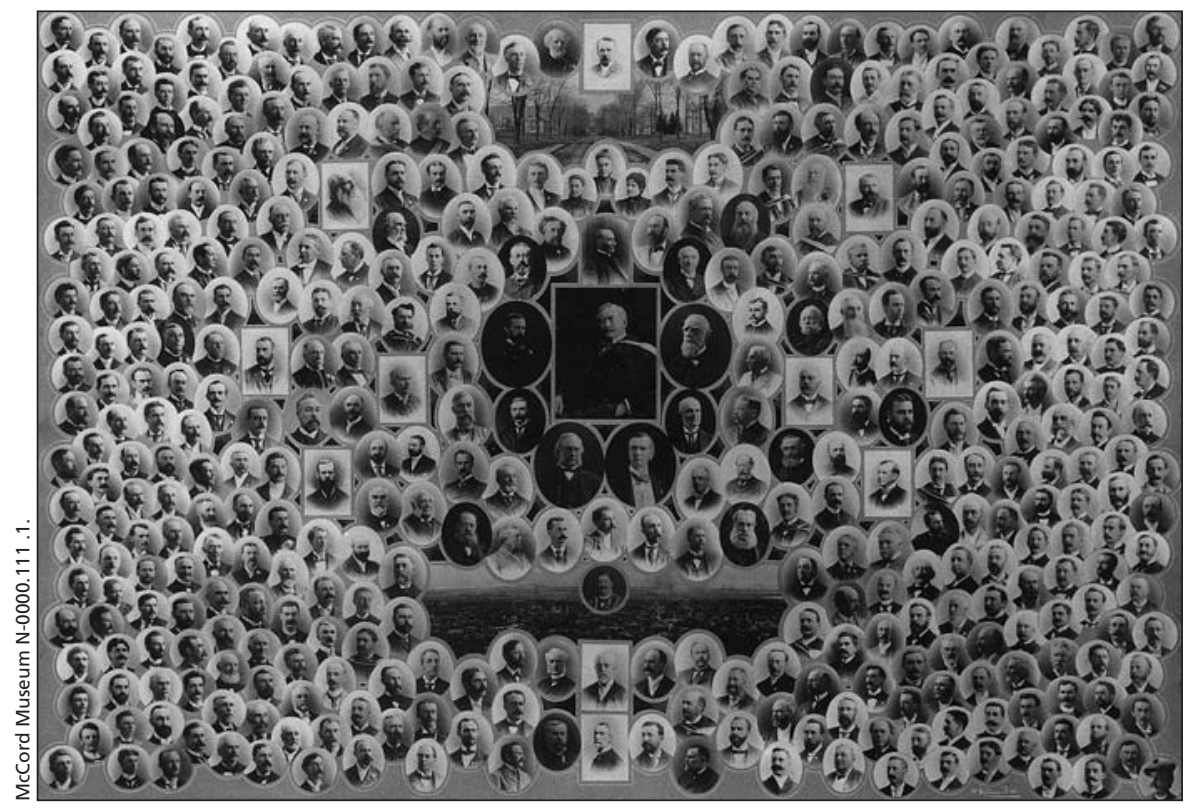

British Medical Association 65th Annual Meeting, Montréal, Que., composite, 1897.

both tongues love and honour our Queen.” Lord Lister, Roddick opined, was the "most illustrious surgeon of our generation ... who stands for the rise and zenith of modern surgery. ... [A]s long as surgery is scientifically discussed [his] name cannot fail to be mentioned." Continuing, Roddick noted how antiseptic and aseptic methods of wound treatment were the "most powerful agency in the development of surgery in this century." Thus Lister's personal presence was an "intellectual stimulus and an energizing force in our deliberations."

Two professional topics addressed in his lecture were medical education and licensing legislation. For Roddick, the training of medical students had changed for the better during the later 19th century as formal didactic lectures had waned, while the role of the laboratory had increased dramatically. "It is in the dissecting room, the chemical, physiological, therapeutic and pathological laboratories" Roddick stated, "that we see the change. These which before were for the most part only 'side shows' are now made to hum with the practical work which is done within them, while demonstrators are moving about busily, engaged in examining and instructing." Clinical teaching had advanced too through the introduction of "bedside teaching" as clinical demonstrators led small groups of stu- dents around hospital wards enabling them "personally to examine the case, to study the physiognomy of disease, and to make deliberate, thorough, and systematic examinations." All of this honed students" "special senses" to gain "careful habits of observation." That this might not appear novel today highlights the extent to which current medical training remains indebted to these innovations.

But the state of Canadian medical licensing unlike education was unsatisfactory, for a "Chinese wall is built round each province, and the frontier is carefully guarded, so that it is unsafe for a medical man to pass from one to the other unarmed with a licence, because of the risk of fine or even imprisonment." (This situation arose from the provisions of the British North America Act that created the Dominion of Canada and endowed each province jurisdiction over education and health affairs.) Worse, still, was that due to an enactment of the British General Medical Council, medical licenses granted by Canadian provinces were no longer recognized throughout the Empire. This situation was intolerable for Roddick, especially as it meant that doctors in Australia, for example, were better off as that colony did not consist of confederated provinces: "We are being punished" Roddick declaimed, "for belonging to a colony whose form of
Government is recognized to be in advance of theirs.'

Roddick took full advantage of the fact that his audience was the largest medical group yet to gather in Canada and was one that included domestic and international medical leaders and statesmen. He drove home his plan of what would eventually become the Medical Council of Canada by advocating a uniform medical curriculum and a central examining and registering board. Such a body would allow Canadian students "passing a Dominion Licensing Board (or whatever it may be called) ... the privilege of practising their profession not only in any part of their native country, but in any part of the world which the British flag flies." Surely, Roddick argued, "legislators of this country will someday (and that not far distant) be induced to see that the system which at present obtains is unworthy of a great and growing country." Despite this plea, only by Roddick's dogged pursuit of legislators for 15 years following would this goal generally reach fruition. ${ }^{5}$

Roddick's 1897 Montréal BMA address was Janus-like. Looking backward, he saw the great strides surgical practice had taken during the Victorian era; also how medical education and training had been enriched because of laboratory science. Looking forward he could see what organized medicine in Canada would eventually become - a national enterprise that was standardized for the benefit and protection of both practitioner and patient.

\section{J.T.H. Connor PhD}

John Clinch Professor of Medical

Humanities and History of Medicine

Faculty of Medicine

Memorial University

St. John's, NL

\section{References}

1. MacDermot HE. Sir Thomas Roddick: his work in medicine and public life. Toronto (ON): Macmillan of Canada; 1938.

2. Connor JTH. Listerism unmasked: antisepsis and asepsis in Victorian Anglo-Canada. J Hist Med Allied Sci 1994;49:207-39.

3. Worboys M. British medicine and its past at Queen Victoria's jubilees and the 1900 centennial. Med Hist 2001;45:461-82.

4. Roddick TG. President's Address, delivered at the sixty-fifth annual meeting of the British Medical Association. BMJ 1897;2:569-76.

5. Kerr RB. History of the Medical Council of Canada. Ottawa (ON): Medical Council of Canada; 1979.

CMAJ 2013. DOI:10.1503/cmaj.120758 